
\title{
Tarraco y Barcino en el Alto Imperio
}

TARRACO AND BARCINO IN THE ROMAN EMPIRE

\author{
Isabel Rodà \\ UAB-ICAC* \\ iroda@icac.cat
}

\section{Fecha recepción 22.02.2016 / Fecha aceptación 22.06.2016}

\section{Resumen}

El artículo se centra en las dos únicas colonias romanas del territorio de la actual Cataluña, en el noreste de Hispania citerior: la capital provincial Tarraco (Tarragona) y la fundación augustea de Barcino (Barcelona). Se intenta hacer un estado de la cuestión y balance de la investigación, poniendo el acento en las hipótesis recientes, algunas de ellas carentes de base, como la existencia de un anfiteatro en Barcino y el improbable cambio de orientación de su templo en el foro.

\section{Palabras clave}

Tarraco, Barcino, arquitectura romana, arqueología urbana.

\section{Abstract}

This paper focuses on the only two coloniae in the territory of modern Catalonia, or north-eastern Hispania Citerior: the provincial capital, Tarraco (Tarragona), and the Augustan foundation of Barcino (Barcelona). It presents the state of the art and a research assessment, highlighting some recent hypotheses, including some with rather poor foundations, such as the existence of an amphitheatre in Barcino and an unlikely change in the orientation of the temple forum.

\section{Key words}

Tarraco, Barcino, roman architecture, urban archaeology.

\footnotetext{
* Trabajo realizado dentro del proyecto I+D: «La explotación y comercio de los recursos naturales en el N. de la Hispania romana: lapis, metalla, aqua» (HAR2011-25011).
} 
Son estas las dos únicas ciudades que en el área catalana tuvieron la categoría de coloniae. Tarraco, como capital de la provincia de Hispania citerior, fue uno de los grandes centros de poder, llegando a ser descrita como una ciudad opulentísima, según Pomponio Mela ${ }^{1}$. Barcino, por su parte, fue una ciudad de dimensiones modestas, pero de gran vitalidad y centro de un activo y productivo territorio. Son, por lo tanto, dos ciudades de perfil muy distinto, pero que, incontestablemente, ejercieron como centros de poder; en algunos casos tenemos constancia de relaciones directas que analizaremos al final de estas páginas y asimismo atenderemos al destacado papel que desempeñó el culto imperial en ambas ciudades como motor de promoción social. En el momento actual se ha iniciado un proyecto de investigación centrado en el estudio de la arquitectura del poder en el noreste de la Tarraconense con una metodología orientada al estudio y representación de los paramentos para la mejor comprensión de los procesos evolutivos entre el alto Imperio y la Antigüedad tardía ${ }^{2}$.

\section{Tarraco. Aspecto monumental}

En el año 2000 Tarraco fue incluida por la UNESCO en la lista del Patrimonio de la Humanidad por la monumentalidad de los restos romanos de la ciudad y de su territorio inmediato, que se extienden en la actualidad por diversos términos municipales.

La arqueología de Tarraco protoimperial ha contado con un fuerte impulso investigador en los últimos tiempos, con publicaciones de referencia, impulsadas por la URV en su serie Documents d'Arqueologia Clàssica y también por el ICAC a través de sus series Documenta e Hic et Nunc dentro de las que caben destacar los 5 volúmenes dedicados al Ager Tarraconensis (Documenta 16) y el volumen de la Planimetria Arqueològica de Tarraco (Documenta 5). Por otro lado, continúa la publicación periódica del Butlletí Arqueològic de la Reial Societat Arqueològica Tarraconense. También se han dado a conocer novedades

1. Cf. nota 23. R. Syme ya confrontó en 1981 ambas ciudades en "Rival cities, notably Tarraco and Barcino", Ktema, 6, 1981, 270-285.

2. Proyecto I+D HAR 2012-36963-C05-02; J. M. Macias, “Tècniques constructives i arquitectura de poder al nord-est de la Tarraconense. Metodologia de representació i paraments analítics per a la comprensió dels procesos evolutius entre l' alt Imperi i l'Antiguitat tardana", QUARHIS. Quaderns d'Arqueologia i Història de la Ciutat de Barcelona, 9, 2013, 189-190, con los resultados dados a conocer en QUARHIS, 12, 2016, 16-143. 
puntuales e importantes en los dos congresos monográficos dedicados a la arqueología de Tarraco y su territorio (Tarraco 99 y las Jornades d'Arqueologia celebradas en noviembre de 2011 cuyas Actas están en preparación). Por último, cabe mencionar las publicaciones diversas del MNAT y la organización desde el año 2012 de los Congresos Internacionales de Arqueología y Mundo Antiguo que llevan el nombre genérico de Tarraco Biennal, el primero de los cuales, con Actas publicadas en 2013, fue dedicado a la memoria de Géza Alföldy y el segundo en 2014 se ha centrado en la figura de Augusto, con las Actas publicadas en dos volúmenes en 2015; el tercero, sobre el circo y su mundo, se ha celebrado en noviembre de 2016.

Los inicios del primer asentamiento romano se remontan a los acontecimientos derivados de la segunda guerra púnica; pero, dejando de lado el recinto amurallado de la parte alta, no exento de polémica en lo que a sus fases y cronología se refiere, hemos de confesar que, a pesar de los avances de la arqueología, todavía nos es insuficientemente conocido el desarrollo urbanístico de Tarraco en la etapa republicana en la que compartió protagonismo con Carthago Nova ${ }^{3}$. Sabemos que antes del 71 a.C. dedicó una inscripción a Pompeyo Magno, que atestigua el uso y la explotación de la piedra de Alcover ya en esta época ${ }^{4}$. No obstante, la ciudad supo cambiar oportunamente de bando, apuntándose al cesariano ya que se grabó en el dorso de la placa de Pompeyo un homenaje a Mucio Escévola y eligió como patrón al influyente Gneo Domicio Calvino, íntimo colaborador de Julio César que había sido designado también por los emporitanos como su patrón ${ }^{5}$. De esta manera, las dos ciudades que habían acogido el desembarco de los romanos en el año 218 a.C. reemprenden bajo César una historia paralela.

3. J. Ruiz de Arbulo, “Tarraco, Carthago Nova y el problema de la capitalidad en la Hispania citerior republicana”, Miscel.lània Arqueològica a J.M. Recasens, Tarragona 1992, 115-130; G. Alföldy, "Wann wurde Tarraco römische Kolonie?”, en G. Paci (Ed.), Epigrafai. Miscelanea Epigrafica in onore di Lidio Gasperini, Macerata 2000, 17-18. Vid. también M. Díaz, J. M. Puche, "El proceso de urbanización de la Tarraco republicana: los niveles constructivos del colector principal de la ciudad”, Revista d'Arqueologia de Ponent, 11, 2003, 291-319; R. Gabriel, "Aproximació a la topografia antiga de Tarragona”, Butlletí Arqueològic, 23, 2001, 281-345. M. Panosa, De Kese a Tarraco. La población de la Tarragona romanorepublicana, amb especial referència a l'epigrafia, Tarragona 2009.

4. G. Alföldy, Die römischen Inschriften von Tarraco (=RIT), Berlín 1975, 1-2= CIL II2/14=Corpus Inscriptionum Latinarum II, editio altera, pars XIV, G. Alföldy (Ed.), fasc. 2, fasc. 3, Berlín 2011-2012, 988, 991; J. Massó, "Inscripció opistògrafa dedicada a Pompeu i a Escèvola” en I. Rodà (Ed.), Tarraco porta de Roma, Tarragona 2001-2002, Barcelona 2001, 73, núm. 30; ID., "Plaque lapidaire d' un piédestal” en P. Sada, D. Cazes (Coords.), Tarraco. Capitale de l'Hispania Citerior, Tolosa 2006, 86, núm. 3.1; B. Díaz, Epigrafía latina republicana de Hispania, Barcelona 2008, 148-149, núm. C59.

5. Así lo atestigua en Tarraco la genial restitución de la inscripción fragmentaria RIT 362=CIL II2/14 977 hecha por G. Alföldy en el año 2000. Cf. J. Massó, "Inscripció dedicada al patró de la colònia Tarraco" en Rodà (Ed.), op. cit., 2001-2002, 79, núm. 39; Díaz, op. cit., 149-150, núm. C60. Sobre los patronos de Emporiae, vid. G. Alföldy, "Cnaeus Domitius Calvinus, patronus von Emporiae”, AEspA, 50-51, 1977-1978, 47-54; I. Rodà, “Els lloctinents de Juli Cèsar, primers patrons d’ Empúries”, Empúries, 48-50, 1986-1989, vol. II, 246-249; Díaz, op. cit., 165-168, núms. C80-82.

Revista de Historiografía 25, 2016, pp. 245-272 
Parece y se acepta de manera generalizada que Julio César fue quien otorgó a Tarraco la categoría jurídica de colonia, siendo el deductor Mucio Escévola ${ }^{6}$. Su esplendor continuó en tiempos de Augusto y los primeros emperadores, convirtiéndose en la capital de la mayor de las provincias del Imperio romano ${ }^{7}$. Durante un cierto periodo de tiempo fue incluso la capital oficiosa del Imperio, ya que Augusto residió en ella durante casi dos años durante su octavo y noveno consulados; ; por lo tanto, donde residía el emperador, allí se encontraba el centro del poder y de las decisiones del gobierno. Las fuentes escritas nos informan sobre las embajadas que el primer emperador recibió en Tarraco y asimismo la inscripción fragmentaria de Mitilene nos hace saber la delegación de ciudadanos de esta polis, devota de la figura del emperador?.

Augusto se sintió bien en Tarragona donde, además de recuperar su salud, gozaba de una popularidad más allá quizás de la adulación. Nos lo trasluce una anécdota que nos ha transmitido Quintiliano (Inst. orat. 6.3.77) sin que tengamos constancia de si se produjo cuando Augusto residía todavía en Tarraco o bien ya había regresado de nuevo a Roma: cuando los tarraconenses mostraron a Augusto el altar que le habían dedicado sobre el que «prodigiosamente» había crecido una palmera, el emperador, con buen humor y fina ironía, respondió que aquello no se debía a prodigio alguno, sino que sencillamente era debido a que no lo debían usar con frecuencia, ya que el fuego sagrado habría imposibilitado el nacimiento de esta planta. Este altar sería el que se representa en las monedas acuñadas en la ciudad ${ }^{10}$.

6. J. Ruiz de Arbulo, "La fundación de la colonia de Tarraco y los estandartes de César", en J. L. Jiménez, A. Ribera (Eds.), Valencia y las primeras ciudades de Hispania, Valencia 2002, 137-156, ID., "La legión de Marte y la fundación de la colonia Tarraco", en J. López (Ed.), Tarraco Biennal. Actes 1er Congrés Internacional d'Arqueologia i Món Antic. Govern i societat a la Hispània romana, novetats epigràfiques. Homenatge a Géza Alföldy (Tarragona 2012), Tarragona 2013, 263-277; J. López, “Glandes inscriptae a l' ager Tarraconensis”, en López (Ed.), op. cit., 175-183.

7. G. Alföldy, "Introducción histórica" en X. Dupré (Ed.), Las capitales provinciales de Hispania 3. Tarragona, colonia Iulia Urbs Triumphalis Tarraco, Roma 2004 (trad. catalana, Tarragona 2008), 8; I. Arrayás, Morfología histórica del territorio de Tarraco (ss. III-I a.C.), Barcelona 2005, 72-86. Cf. además G. Alföldy, "Tàrraco, capital de la Hispània Citerior", Kesse, 28, 1998, 7-12, e ID., "Tarraco, capital de la provincia més gran de l' Imperi romà", en Rodà (Ed.), op. cit., 2001-2002, 26-28.

8. Suetonio, Aug. 26.3; G. Alföldy, Tarraco, Tarragona 1991; J.M. Abascal, "Los tres viajes de Augusto a Hispania y su relación con la promoción jurídica de ciudades”, Iberia, 9, 2006, 63-78, 65 y 68-70.

9. D. Fishwick, "The Altar of Augustus and the Municipal Cult of Tarraco", Madrider Mitteilungen, 23, 1982, 223; I. Arrayás, “Tarraco, omphalós del món grecoromà. L'ambaixada de Mitilene a Tarraco", en M. Prevosti, J. López, J. Guitart (Eds.), Ager Tarraconensis 5. Actes del Simposi Internacional (Tarragona 2010), Documenta 16, Tarragona 2013, 425-435; J.M. Abascal, "El decreto de Mytilene y Tarraco. Una nota", Studia Historica. Historia Antigua, 32, 2014, Augusto y el Imperio romano, 77-89.

10. A Burnett, M. Amandry, P. P. Ripollès, Roman Provincial Coinage I. From the Death of Caesar to the Death of Vitellius (44 BC-AD 69), Londres-París 1992, 104-105, núms. 218, 221, 225, 231; P. Capus, "Sesterce de l' atelier monétaire de Tarraco", en Sada, Cazes (Coords.), op. cit., 91, núm. 3.6; Fishwick, loc. cit., ID., Precinct, Temple, Altar in Roman Spain. Studies in the Imperial Monuments of Mérida and Tarragona, Abingdon 2013; J. Ruiz de Arbulo, R. Mar, J. Domingo, I. Fiz, "Etapas y elementos de la decoración arquitectónica en el desarrollo monumental de la ciudad de Tarraco (s. II a.C.-I d.C.)", en S.F. Ramallo 
Nos parece más viable que hubiera estado ubicado en el espacio público del foro de la colonia y no en el área del llamado foro provincial, como se ha propuesto recientemente ${ }^{11}$, ya que hay que tener en cuenta que fue dedicado en vida del propio Augusto, lejos todavía de la institución del culto imperial a nivel provincial.

Un nuevo viaje de Augusto a tierras hispánicas tuvo lugar en 16-15 a.C. cuando el historiador Casio Dión comenta que fundó numerosas ciudades en Hispania y la Narbonense ${ }^{12}$.

A partir de la división provincial de inicios del Imperio, Tarraco fue la sede del gobernador, el legatus Augusti pro praetore prouinciae Hispaniae citerioris, asistido por unos legati iuridici $^{13}$. Gracias a las fuentes epigráficas conocemos unos $50^{14}$. Residía en el praetorium consulare, conocido por una inscripción ${ }^{15}$, pero desconocemos su ubicación concreta. Con toda probabilidad estaría situado en el área del denominado foro provincial cuando éste fue construido, siendo el lugar más idóneo una de las dos torres que cerraban la gran plaza de representación sobre el circo, quizá la conocida como torre del pretorio o de Pilatos ${ }^{16}$.

En relación con la administración provincial cabe situar la presencia de una guarnición miliar cuyas funciones eran las de estar al servicio del gobernador con tareas diversas que también se extendían a la vigilancia de la costa (prefectura de la ora maritima). Tarraco no proporcionó demasiados elementos a las legiones, pero sí que acogió en cambio a un buen número de veteranos que encontraron en la ciudad un buen escenario para su retiro ${ }^{17}$.

(Ed.), La decoración arquitectónica en las ciudades romanas de Occidente (Cartagena 2003), Murcia 2004, 123-126; J. Ruiz de Arbulo, "El altar y el templo de Augusto en la colonia Tarraco. Estado de la cuestión”, en J. M. Noguera (Ed.), El foro como espacio regulador de la vida cívica y religiosa de las ciudades romanas de Hispania (Lorca 2002), Murcia 2009, 155-189.

11. R. Mar et alii, Tarraco. Arquitectura y urbanismo de una capital provincial romana I. De la Tarragona ibérica a la construcción del templo de Augusto, Tarragona 2012, 345-348, 369.

12. Casio Dión 54.23.7 y 25; Abascal, loc. cit., 2006, 65-66, 70.

13. P. Ozcáriz, La administración de la provincia Hispania citerior durante el Alto Imperio romano, Instrumenta 44, Barcelona 2013, 97-179 para gobernadores y legati.

14. G. Alföldy, Fasti Hispanienses, Wiesbaden 1969, 3-66; RIT 34, 89-90, 128, 130-132, 135, 139-140, 142 143, 150-151. En las excavaciones de Ca la Garça (pl. dels Àngels-pl. Rovellat) de Tarragona se descubrió el ángulo superior izquierdo de un pedestal atribuible al gobernador Rutilius Pudens Crispinus que hasta ahora sólo conocíamos por una inscripción de Roma: CIL II2/14, 992 (Alföldy, op. cit. 1969, 59-60). Cf. sobre gobernadores y administración provincial, G. Alföldy, "Desde el nacimiento hasta el apogeo de la cultura epigráfica de Tarraco", en L. Hernández Guerra, L. Sagredo San Eustaquio (Eds.), Actas del I Congreso Internacional de Historia Antigua. La Península Ibérica hace 2000 años, Valladolid 2001, 61-74 y Ozcáriz, op. cit.

15. RIT 34=CIL II2/14, 837.

16. G. Alföldy, op. cit., 1991, 45.

17. P. Le Roux, "Ejército y sociedad en la Tarraco romana”, Butlletí Arqueològic, 19-20, 1997-1998, 83107; ID., "Military Inscriptions", en A. Morillo, J. Aurrecoechea (Eds.), The Roman Army in Hispania. An Archaeological Guide, León 2006, 451-471; ID., "Las inscripciones militares”, en A. Morillo, J. Aurrecoechea (Eds.), El ejército romano en Hispania. Guía arqueológica, León 2007, 481-501; G. Alföldy, "The Roman Army at Tarraco", en Morillo, Aurrecoechea (Eds.), op. cit., 2006, 473-492; ID., "El ejército romano en Tarraco", en Morillo, Aurrecoechea (Eds.), op. cit., 2007, 503-521. 
En la Tarragona romana una institución clave fue el concilium prouinciae Hispaniae citerioris que tenía su sede en la parte alta de la ciudad, correspondiente al foro provincial ${ }^{18}$. Este concilium reunía las delegaciones de los siete conventos jurídicos de la provincia citerior. Se ha supuesto que este concilium funcionaría, como mínimo, a partir de año 15 d.C.

Inmediatamente después de la muerte de Augusto, una embajada de tarraconenses se desplazó el 15 d.C. a Roma con la intención del solicitar al nuevo príncipe permiso para erigir un gran templo en honor del primer emperador y padre adoptivo del reinante. Tiberio concedió con sumo gusto el permiso y, según nos informa el historiador Tácito, este hecho fue considerado un ejemplo para todas las provincias de Imperio, frase que ha hecho correr litros de tinta, pero que, dado el énfasis del proceso, nos inclinamos a pensar que el templo tendría que superar la categoría municipal para entrar en las esferas del ámbito provincial, aunque no podamos hablar todavía de una organización bien constituida del culto imperial a este nivel ya que nos faltan datos al respecto ${ }^{19}$.

En efecto, los tarraconenses, inmediatamente después de regresar su embajada de Roma, decidieron construir un templo de dimensiones excepcionales, al parecer octástilo, similar al templo de Mars Ultor en el foro de Augusto. De nuevo, nos encontramos con un edificio extraordinario ya que son pocos los templos octástilos en las provincias del Imperio y en todos los casos se trata de edificios singulares.

Durante siglos se ha discutido el emplazamiento de este templo, pero ahora ya lo sabemos y en realidad está donde debía estar: coronando la parte alta de la ciudad, bajo la Catedral actual ${ }^{20}$. Era lo lógico ya que para un templo fuera de lo corriente se había de elegir la mejor y más espectacular ubicación, pero era necesario demostrarlo. Ello ha sido posible gracias a las prospecciones geofísicas de 2007 y a las excavaciones de los años 2010 y 2011, llevadas a cabo en el interior de la Catedral.

Seguramente la construcción de un recinto de culto tan grandioso se prolongó durante bastantes años, pero los tarraconenses, diligentes y con ganas de exhibir su proyecto, se

18. J. M. Macias et alii, Planimetria arqueològica de Tarraco, Documenta 5, Tarragona 2007, 222 para las numerosas referencias sobre la plaza y el recinto de culto del concilium; Ruiz de Arbulo et alii, en Ramallo (Ed.), op. cit., 142-143.

19. G. Alföldy, "In omnes provincias exemplum: Hispanien und das Imperium Romanum”, Hispania Terra Omnibus Felicior (Cividale 2001), Pisa 2002, 183-199; D. Fishwick, "The Temple of Augustus at Tarraco", Latomus, 58, 1999, 121-138; ID., Precinct, Temple, Altar in Roman Spain. Studies in the Imperial Monuments of Mérida and Tarragona, Abingdon 2013; I. Rodà, "Documentos e imágenes de culto imperial en la Tarraconense septentrional”, en T. Nogales, J. González (Eds.), Culto Imperial: política y poder (Mérida 2006), Roma 2007, 743-748; EAD., "Espacios de representación en los foros de Hispania”, en Noguera (Ed.), op. cit., 2009, 69-87.

20. Una primera noticia en J. M. Macias et alii, "L' arqueologia de la catedral de Tarragona. La memòria de les pedres”, La catedral de Tarragona. In sede. 10 anys de pla director de restauració, Tarragona 2007, 151213 y "La construcción del recinto imperial de Tarraco (provincia Hispania Citerior)", en J. López, O. Martin (Eds.), Actes del Congrés Internacional en homenatge a Th. Haushild (Tarragona 2009), Butlletí Arqueològic, 32, 2010, 423-479; J. M. Macias et alii, Praesidium, templum et ecclesia. Les intervencions arqueologiques a la Catedral de Tarragona 2010-2011. Memòria d'una exposició temporal, Tarragona 2012. 
apresuraron a acuñar sestercios con la representación de la fachada octástila del templo y con la imagen de Augusto entronizado y divinizado, especificando para mayor claridad Deo Augusto $^{21}$. Seguramente estas monedas circulaban con un evidente matiz propagandístico en el momento en el que las obras del templo estaban apenas iniciadas. El hallazgo de un pequeño fragmento de un dedo colosal correspondiente al pie izquierdo ha permitido proponer una hipotética restitución de la estatua de culto del dios Augusto en su templo de Tarraco ${ }^{22}$.

A mediados del siglo I d.C. Tarraco era una ciudad opulenta ${ }^{23}$, en pleno desarrollo con todo el sector de la parte alta de Tarragona en remodelación. Continuó experimentando una remodelación total bajo el reinado de los emperadores flavios, que hizo desaparecer buena parte de los trazos de las fases anteriores ya que, en ciertos puntos, los rebajes de terreno llegaron a la misma roca madre. Con todo, parece que este proceso tuvo su inicio en los últimos años de la dinastía julio-claudia ${ }^{24}$.

Vespasiano, al inicio de su gobierno, privilegió las ciudades hispánicas con la concesión del ius Latii $^{25}$, teniendo en cuenta que Hispania había llevado a cabo un papel clave en el llamado año de los cuatro emperadores consecutivo a la muerte de Nerón (68 d.C.). Impulsó también la transformación de la capital provincial, Tarraco, con unas obras ingentes que llevarían a la suntuosa estructuración en tres terrazas, la inferior de las cuales, correspondiente al circo, se acabaría en tiempos de Domiciano; con anterioridad, en la zona de la arena (actual plaza de la Font), había unas figlinae y unos horrea ${ }^{26}$. Era una operación urbanística ambiciosa que habría de dotar de una mayor monumentalidad al área circun-

21. Burnett, Amandry, Ripollès, op. cit., 104-105, núms. 219, 222. 224, 226; P. Capus, en Sada, Cazes (Coords.), op. cit., 90, núm. 3.5.

22. Mar et alii, op. cit., 2012, 362.

23. Pomponio Mela (2.90) dice: Tarraco urbs est in his oris maritimarum opulentissima.

24. Ted'A, Un abocador del segle V d.C. en el fòrum provincial de Tàrraco, Tarragona 1989 y X. Dupré, "Un gran complejo provincial de época flavia en Tarragona", en W. Trillmich, P. Zanker (Eds.), Stadtbild und Ideologie. Die Monumentalisierung hispanischer Städte zwischen Republik und Kaiserzeit (Madrid 1987), Munich 1990, 319-325 para la unidad constructiva de época flavia. Para los elementos flavios, Ruiz de Arbulo et alii, en Ramallo (Ed.), op. cit., 139-142. Más recientemente se ha comenzado a intuir que los movimientos edilicios podían haberse iniciado a final de los Julio-claudios; cf. P. Pensabene, R. Mar, "Dos frisos marmóreos de la acrópolis de Tarraco, el templo de Augusto y el complejo provincial de culto imperial”, en J. Ruiz de Arbulo (Ed.), Simulacra Romae. Roma y las capitales provinciales del Occidente europeo. Estudios arqueológicos (Tarragona 2002), Tarragona 2004, 78, J. M. Macias et alii, Planimetria arqueològica de Tarraco, 774-775; Mar et alii, op. cit., 2012, 352-359. J.M. Macias et alii, "Nuevos elementos escultóricos del recinto de culto del Concilium Provinciae Hispaniae Citerioris (Tarraco, Hispania Citerior)", en T. Nogales, I. Rodà, (Eds.), Roma y las provincias. Modelo y difusión (Mérida 2009), Roma, 2011, vol. II, 873-886.

25. J. Andreu, Edictum, municipium y lex. Hispania en época Flavia (69-96 d.C.), Oxford 2004; S. Keay, "La transformazione della città nelle province iberiche", F. Coarelli, (Ed.) Divus Vespasianus. II bimillenario dei Flavi, Milán 2009, 372-377.

26. J. M. Macias et alii, 85, núm. 238; J. López, Ll. Piñol, “Tarragona romana”, El món de l’aigua. Història de l'abastament d'aigua a Tarragona, Tarragona 1998, 20-49 y Terracotes arquitectònicues romanes. Les troballes de la plaça de la Font, Hic et Nunc 4, Tarragona 2008; J. López, Ll. Piñol, V. Revilla, "Modelos 
dante del templo de Augusto y haría que Tarraco dispusiera de una de las plazas más grandes construidas en una ciudad romana. La espectacularidad y el impacto visual se verían magnificados por la posición elevada y estratégica sobre el mar y sobre la vía Augusta que pasaba bajo la colina natural sobre la que se asentó la primera Tarragona. La vía Augusta pasaba junto a la fachada meridional del circo, separando el tejido urbano de la capital provincial del de la ciudad colonial. En la entrada y la salida de la ciudad, la vía Augusta estaba bordeada por tumbas de diversa entidad; una de las más destacadas del siglo I d.C. es la famosa torre conocida como de los Escipiones que se alza todavía sobre la carretera nacional 340, continuadora de un trazado milenario ${ }^{27}$.

El agua en la parte alta de la Tarragona protoimperial estaba asegurada por la aportación de los dos ramales del acueducto del río Gaià con un hipotético castellum aquae en el «turó de l' Oliva» y, en la zona ocupada por la colonia propiamente dicha, por el acueducto del Francolí, con el tramo monumental del Puente del Diablo o de les Ferreres y el gran lago subterráneo bajo el tejido urbano ${ }^{28}$.

En el área de la colonia, la ciudad se iba desarrollando ${ }^{29}$. Una hipótesis muy atractiva ha propuesto identificar una estructura formada por unas piedras irregulares con perforaciones circulares como el auguraculum a partir del cual se proyectó el trazado urbano de la ciudad ${ }^{30}$.

Paulatinamente, vamos teniendo pruebas continuadas de la monumentalidad de la arquitectura pública alrededor del foro colonial ${ }^{31}$. Las últimas investigaciones han identificado el Capitolio de época republicana, la arquitectura más antigua ${ }^{32}$. De época protoimperial sería la basílica, con una gran refacción en época de Tiberio, en la que se abría el aula de culto

itálicos y artesanado provincial: las lastras Campana de Tarraco y su territorio", en Nogales, Rodà, (Eds.), op. cit., 2011, 887-895.

27. J. A. Remolà, "Arquitectura funeraria" en Dupré (Ed.), op. cit., 83-95. Para un estado actual de los hallazgos varios y sepulcrales, vid. Macias et alii, op. cit., 2007, 221, 223 con las referencias anteriores y J. Ciurana, "Les àrees funeràries de l'ager Tarraconensis (segles I-III d.C.)", en Prevosti, López, Guitart (Eds.), op. cit., 2013, 119-140.

28. Macias et alii, op. cit., 2007, núms. 166, 181, 858, 697, 699, 719, 721, 726, 728, 729 y 733 para los hallazgos de tramos de los acueductos del Gaià y del Francolí y fig. 18 para el trazado. Sobre el lago subterráneo y el cuniculus, núms. 15, 238, 464, 469 como elementos más seguros. Cf. de manera global sobre el agua en Tarraco, P. Sada (Dir.), Tarraco i l'aigua, Tarragona 2004 y López, Piñol, op. cit.

29. R. Mar, P. Pensabene, "L' urbanisme a Tàrraco", en Rodà (Ed.), op. cit., 2001, 37-45; Gabriel, loc. cit.

30. C. Salom, "El auguraculum de la colonia Tarraco", AEspA, 79, 2006, 69-87; Macias et alii, op. cit., 2007, 112, núm. 427 (CSG); J. M. Palet, H. A. Orengo, "Les centuriacions de l' ager Tarraconensis: organització i concepcions de l'espai/The Centuriations of the ager Tarraconensis: spatial organisation and conceptualisation", en M. Prevosti, J. Guitart (Dirs. científ.), Ager Tarraconensis 1. Aspectes històrics i marc natural, Documenta 16, Tarragona 2010, 148-149.

31. X. Aquilué, "Arquitectura oficial", en Dupré (Ed.), op. cit., 42-46.

32. J. Ruiz de Arbulo, D. Vivó, R. Mar, "El capitolio de Tarraco. Identificación y primeras observaciones", en D. Vaquerizo, J.F. Murillo (Eds.), El concepto de lo provincial en el mundo antiguo. Homenaje a Pilar León Alonso, vol. I, Córdoba 2006, 391-417; J. M. Macias et alii, 114, núm. 434 (JRB); R. Mar, J. Ruiz de Arbulo, D. Vivó, "Las tres fases constructivas del Capitolio de Tarragona”, en J. López, O. Martin (Eds.), op. cit. Actes del Congrés Internacional en homenatge a Th. Hauschild (Tarragona 2009), Butlletí Arqueològic, 32, 2010, 
dinástico ${ }^{33}$ donde se han encontrado abundantes restos escultóricos y epigráficos ${ }^{34}$ y elementos de decoración arquitectónica que se interpretaron como pertenecientes a un arco de la época de Augusto pero que más recientemente se han puesto en relación con la decoración de la fachada de la basílica ${ }^{35}$.

En relación con este recinto del foro ha de ponerse el vecino teatro ${ }^{36}$ con un circuito que enlazaría ambos equipamientos urbanos con el fin de conformar el recorrido de las procesiones de culto imperial, como sucede en otras ciudades de la provincia ${ }^{37}$; en estas celebraciones debería haber participado el portador de la campanita de bronce, cuya inscripción parece que se ha podido interpretar de manera convincente ${ }^{38}$. El teatro se dotó en época augustea y julio-claudia de una decoración escultórica imponente, el elemento más antiguo de la cual fue el gran vaso marmóreo con relieves vegetales que puede fecharse a mediados del siglo I a.C. ${ }^{39}$. Una datación también alta, augustea, parece cuadrar con el altar de mármol lunense dedicado al numen o genio del emperador que

507-540; Mar et alii, op. cit., 2012, 162-180; R. Mar, J. Ruiz de Arbulo, D. Vivó, "El capitolio de Tarraco", en I. Piso, R. Varga (Eds.), Trajan und seine Städte (Cluj-Napoca 2013), Cluj-Napoca 2014, 37-68.

33. R. Mar, J. Ruiz de Arbulo, "Tribunal/Aedes Augusti. Algunos ejemplos hispanos de la introducción del culto imperial en las basílicas forenses" en J. González, J. Arce (Eds.), Estudios sobre la Tabula Siarensis, Anejos de AEspA IX, Madrid 1988, 277-304; Ruiz de Arbulo, Vivó, Mar, en Vaquerizo, Murillo (Eds.), op. cit.; Macias et alii, op. cit., 2007, 115-116, núm. 439 (JRB).

34. E. M. Koppel, Die römischen Skulpturen von Tarraco, Berlín 1985, 32-51, núms. 44-74; EAD., "El foro municipal de Tarraco y su decoración escultórica", Actas del XVII CNA (Logroño 1983), Zaragoza 1985, 841-857; EAD., "Retratos de Tiberio y de Nero Caesar en Tarragona", en P. León, T. Nogales (Eds.) Actas de la III Reunión sobre escultura Romana en Hispania (Córdoba 1997), Madrid 2000, 81-91; Ruiz de Arbulo et alii, en Ramallo (Ed.), op. cit., 135-138.

35. E. M. Koppel, "Relieves arquitectónicos de Tarragona", en Trillmich, Zanker (Eds.), op. cit., 327-340; EAD., "La escultura" en Dupré (Ed.), loc. cit., 118; X. Dupré, "Los arcos honoríficos de Tarraco", La ciudad en el mundo romano. Actas del XIV Congreso Internacional de Arqueología Clásica (Tarragona 1993), vol. 1, Tarragona 1994, 177-188; Ruiz de Arbulo et alii, en Ramallo (Ed.), op. cit., 138; Ruiz de Arbulo, Vivó, Mar, en Vaquerizo, Murillo (Eds.), op. cit., 398, fig. 8; M. Lamuà et alii, "La fachada oriental de la basílica forense de Tarraco. El monumento de los cautivos y el chalcidicum de culto imperial", en Nogales, Rodà (Eds.), $o p$. cit., 2011, 863-872; Mar et alii, op. cit., 2012, 268-278.

36. X. Dupré, "Edificios de espectáculo", en Dupré (Ed.), op. cit., 55-60; Macias et alii, op. cit., 2007, 119 127; Ruiz de Arbulo, Vivó, Mar, en Vaquerizo, Murillo (Eds.), op. cit., 392, fig. 1, 410, fig. 16; J. Ruiz de Arbulo et alii, en Ramallo (Ed.), op. cit., 127-132 y 145; Mar et alii, op. cit., 2012, 286-317.

37. Se ha podido reconstruir el itinerario foro-teatro, por ejemplo, en Bílbilis (Calatayud); vid. M. MartínBueno, "El culto imperial en el valle del Ebro", en Nogales, González (Eds.), op. cit., 731-734. Vid. un panorama más general en P. Gros, "Théatre et culte impérial en Gaule Narbonnaise et dans la Péninsule Ibérique" en Trillmich, Zanker (Eds.), op. cit., 381-390.

38. R. Comes, I. Rodà (Eds.), Scripta manent. La memòria escrita dels romans, Barcelona 2002 (=Scripta manent), 241; Rodà, en Nogales, González (Eds.), op. cit., 2007, 745-748; EAD., "Espacios de representación en los foros de Hispania" en Noguera (Ed.), op. cit., 69-87; CIL II2/14, 1226.

39. E. M. Koppel, I. Rodà, "Escultura decorativa de la zona nororiental del conventus Tarraconensis", en J. Massó, P. Sada (Eds.), Actes de la II Reunió sobre Escultura Romana a Hispània (Tarragona 1995), Tarragona 1996, 135-139, figs. 1-3; J. Massó, "Fragments d' un vas monumental decorat" en Rodà (Ed.), op. cit., 2001, 


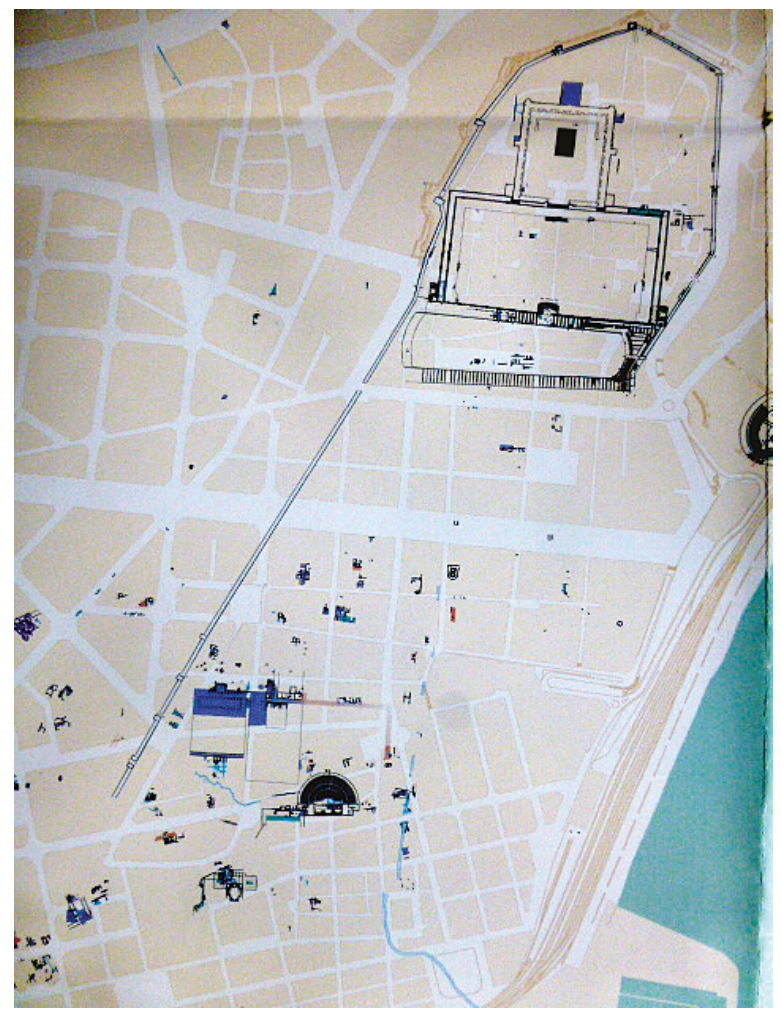

1.- Planta general de los restos arqueológicos de Tarraco y retícula urbana actual. E: 1:6.000. J. M. Macias et alii, 2007, recull cartogràfic.

correspondería a época protoimperial y, a pesar de no poderse identificar con el altar de Augusto mencionado por Quintiliano y representado en las monedas, es un testimonio del homenaje religioso al emperador ${ }^{40}$. La scaenae frons se ornamentó con imágenes del emperador Augusto y su familia que constituyeron el primer grupo escultórico que se iría ampliando con los emperadores sucesivos ${ }^{41}$.

81, núm. 41; ID., "Morceaux, en deux fragments, de la partie supérieure d' un vase monumental décoré de motifs végétaux”, en Sada, Cazes (Coords.), op. cit., 101, núm. 4.6.

40. RIT 48=CIL II2/14, 851; C. Castillo, "Un trienio de epigrafía latina en Hispania: logros y perspectivas", Unidad y pluralidad en el mundo antiguo. Actas del VI Congreso Español de Estudios Clásicos (Sevilla 1981), vol. I, Madrid 1983, 101-1245; Scripta Manent, op. cit., 228, núm. 66.

41. E. M. Koppel, "Esculturas del teatro romano de Tarragona”, Actas del Simposio: El teatro en la Hispania romana, Badajoz 1982, 139-152; EAD., op. cit., 1985, 13-32, núms. 1-43, EAD., "L'escultura” en Dupré (Ed.), op. cit., 116-117; R. Mar et alii, "La scaenae frons del teatro de Tarraco. Una propuesta de restitución", en S. 
En la zona del teatro cobran relevancia otras dos grandes infraestructuras: las termas y el puerto, exponentes de la remodelación de la zona periférica sur-occidental en los inicios del Imperio: las termas más cercanas al teatro de época altoimperial son las descubiertas en la calle de Apodaca, sin que, de momento, tengamos constancia de termas de época republicana en la Tarragona romana ${ }^{42}$. Por otra parte, sabemos que Augusto se benefició del valor curativo de los baños termales en Tarragona, siguiendo las indicaciones de su médico Musa ${ }^{43}$.

No podemos olvidar la importancia que tuvo el puerto para el desarrollo de la ciudad. A partir de la época augustea se hacen notorios los trabajos para construir nuevos recintos portuarios y para organizar una fachada marítima monumental a lo que contribuyeron sin duda las moles del teatro y las termas. Hay que hacer alusión de manera especial a las excavaciones de la zona conocida como PERI 2 que ha permitido poner al descubierto un conjunto de almacenes y una fuente republicana monumental de tipo helenístico que es uno de los elementos más singulares de la Tarraco republicana ${ }^{44}$.

Con todo ello, podemos calcular que, con el desarrollo de la periferia urbana, Tarraco podría haber llegado a tener una superficie de unas 80 o 90 hectáreas, de las cuales unas 5560 corresponderían al área intramuros. La parte alta de la ciudad, destinada a los edificios públicos de la capital provincial, habría ocupado en total 19 hectáreas.

F. Ramallo, N. Roering (Eds.) La scaenae frons en la arquitectura teatral romana (Cartagena 2009), Murcia 2010, 189-197; R. Mar et alii, op. cit., 2012, 318-321.

42. J. M. Macias, "Els banys termals a Tàrraco: urbs i negotium", en Sada (Dir.), op. cit., 69-80; M. Díaz et alii, "Elementos arquitectónicos del área termal pública del puerto de Tarraco", en Ramallo (Ed.), loc. cit., 2004, 447-449; Macias et alii, op. cit., 2007, 223 para las referencias a las termas y 102, núm. 355 para las de la calle Apodaca (PBP-JRP-JMS); J. M. Macias, "L' arquitectura termal a Tarraco i el seu territorium: reflexions sense resposta”, en López, Martin, (Eds.), op. cit., 541-567.

43. Suetonio, Augustus 81; E. Gozalbes, "Los baños y la curación de Octavio Augusto en Tarraco", Termalismo antiguo. I Congreso Peninsular (La Rioja 1996), Madrid 1997, 241-246.

44. M. Adserias, C. A. Pociña, J. A. Remolà, "L' hàbitat suburbà portuari de l' antiga Tàrraco. Excavacions al sector afectat pel PERI 2 (Jaume I-Tabacalera)", en J. Ruiz de Arbulo (Ed.), Tarraco 99, Arqueologia d'una capital provincial romana (Tarragona 15-17 de abril de 1999), Documents d'Arqueologia Clàssica, 3, Tarragona 2000, 17-154; J.A. Remolà, A. Vilaseca, "Intervencions arqueològiques al PERI-2, sector Tabacalera, de Tarragona”, Tribuna d'Arqueologia 1997-1998, Barcelona 2000, 77-95; C. A. Pociña, J. A. Remolà, "Nuevas aportaciones al conocimiento del puerto de Tarraco (Hispania Tarraconensis)", Saguntum 33, 2001, 85-96; Macias et alii, op. cit., 2007, 221-222 para las referencias al puerto; J. A. Remolà, J. Sánchez, "El sector occidental del suburbi portuari de Tarraco", en López, Martin (Eds.), op. cit, 595-618. Para la fuente, J. A. Remolà, C. A. Pociña, "La Font dels lleons", en Sada (Dir.), op. cit., 53-66; J. A. Remolà, E. Ramon, "Tarraco, origine et evolution d' une ville", en Sada, Cazes (Coords.), op. cit., 36-37; Macias et alii, op. cit., 2007, 144-145, núm. 588 (JLV); I. Teixell, La font dels lleons: aproximació a la circulació monetària de Tàrraco (segona meitat del segle II dC-primer quart del V dC), Tarragona 2008, 28-29; Mar et alii, op. cit., 2012, 188-192. 


\section{Tarraco. El culto imperial}

La estancia en Tarraco del emperador Augusto propició sin duda el profundo arraigo de una de las instituciones de gobierno que mostró su incidencia tanto en el terreno organizativo como en el propagandístico y social. El montaje en torno a la figura del emperador y su familia constituyó un pilar fundamental del Estado romano y su eficacia quedó demostrada de manera continuada y reiterada en todas las diversas dinastías del Alto Imperio a lo largo y ancho de la dilatada geografía que llegó a abarcar.

Un gran peso específico tuvo sin duda en Tarraco la construcción del templo dedicado a Augusto al que ya hemos hecho referencia más arriba. Asimismo los grandes edificios de espectáculos estarían relacionados con el culto imperial, como hemos visto al hablar del teatro. Sabemos, además, que el anfiteatro fue construido en el siglo II d.C. por un flamen del culto imperial a nivel provincial, para nosotros anónimo ${ }^{45}$.

En el momento presente no tenemos testimonios epigráficos de los sacerdocios provinciales antes de la época flavia. A partir de entonces el concilium P.H.C. fue presidido por el flamen prouinciae Hispaniae citerioris que era elegido anualmente entre aquellos que habían desempeñado con anterioridad, por regla general, una brillante carrera municipal y de esta manera se abría para ellos la puerta del ordo equester, es decir el ascenso a la categoría de los caballeros, demostrando una vez más que el culto imperial constituía un importante factor para la promoción social y personal. Verdaderamente es impactante el elevado número de personajes tarraconenses que consiguieron su ingreso en esta clase social dentro de una ciudad caracterizada por su carácter abierto en comparación con otras ciudades, como Sagunto, mucho más cerradas. Este hecho benefició, naturalmente, a las otras clases sociales de Tarraco, como asimismo ocurrió en Barcino ${ }^{46}$.

Hemos de pensar también que, sin duda, esta movilidad se vería favorecida por la presencia en la Tarragona protoimperial de personajes notables como el Licinio Sura de época augustea y antepasado homónimo del íntimo colaborador del emperador Trajano, que mandó construir el arco de Berà sobre la vía Augusta ${ }^{47}$.

Uno de los rasgos específicos de la epigrafía de Tarraco es el elevado número de pedestales erigidos en honor de los flamines provinciales ${ }^{48}$, las enseñas de los cuales se grabaron en los relieves que rodeaban el recinto de culto imperial y que en parte se ex-

45. G. Alföldy en Ted'A, op. cit., 131-132; CIL II2/14, 1109.

46. G. Alföldy, "Drei städtische Eliten in römischen Hispanien”, Gerión, 1984, 193-238; I. Rodà, "La promoción de las elites en las ciudades del conventus Tarraconensis“, en F.J. Navarro (Ed.), Pluralidad e integración en el mundo romano (Pamplona-Olite 2008), Pamplona 2010, 177-188.

47. X. Dupré, L'arc romà de Berà (Hispania Citerior), Monografías de la EEHAR 20, Roma 1994; ID., loc. cit., 1994; G. Alföldy, "Der römische Bogen über der Via Augusta bei Tarraco (Arc de Berà) und seine Inschrift", Klio 78, 1996, 158-170; I. Rodà, "Lucius Licinius Sura Hispanus», I. Piso, Varga (Eds.), op. cit., 21-35; CIL II2/14, 2332.

48. G. Alföldy, Flamines Provinciae Hispaniae Citerioris, Anejos de AEspA, 6, Madrid 1973; RIT, p. 508; CIL II2/14, 1109-1199. 
hiben empotrados en los muros del claustro de la Catedral ${ }^{49}$. Las estatuas en su honor poblarían la zona pública, dando testimonio del poder real de la institución con una gran influencia en las esferas del gobierno.

Junto al flamen provincial estaba la flaminica, con frecuencia su mujer, que era el único cargo de representación al que tenía acceso el estamento femenino ${ }^{50}$. Además, una serie de funcionarios, de personal subalterno y de libertos aseguraba el funcionamiento de culto y su difusión y omnipresencia.

El culto al emperador a nivel municipal fue uno de los motores de la vida ciudadana tanto en Tarraco como en otras ciudades del Imperio, especialmente las del litoral y en las más profundamente romanizadas. El cargo de flamen culminaba la carrera de los magistrados municipales y el sevirato augustal permitió la promoción de aquellos individuos que, habiendo nacido esclavos, conseguían su libertad y podían de este modo asegurarse una representación, abriendo las puertas de los cargos municipales a sus hijos y descendientes. Son ciertamente numerosos los seviros augustales atestiguados en la epigrafía de Tarraco que, además, cuenta con testimonios de los cargos de magistri y decuriones Larum ${ }^{51}$.

En la colonia de Tarraco, el culto se organizó en torno a dos conjuntos públicos visibles parcialmente: el foro de la parte baja de la ciudad y el teatro, a los que hemos hecho referencia más arriba.

\section{Barcino. Aspecto monumental}

La trayectoria histórica y monumental de Barcino es bien diferente de la que nos presenta Tarraco. La fundación de Barcino, una ciudad ex nouo, se inserta dentro del amplio programa de reestructuración acometido por Augusto y Agripa una vez finalizada la segunda fase de las guerras cántabras (19 a.C.), coincidiendo con el nuevo viaje de Augusto de los años 16-15 a.C. al que se refiere Casio Dión y que hemos recordado al hablar de Tarraco ${ }^{52}$. Es el mismo contexto en el que se fundó Caesar Augusta (Zaragoza) y se remodeló el trazado de la vía Augusta ${ }^{53}$.

La nueva colonia tuvo una titulación ampulosa: colonia Iulia Augusta Faventia Paterna Barcino. En un lejano 1976, cuando se pensaba que gran parte de las ciudades hispanas fueron fundadas en el segundo viaje de Augusto, nos pareció que los dos epítetos de Iulia y

49. Macias et alii, op. cit., 2007, 52, núm. 18 con la bibliografía anterior.

50. Alföldy, op. cit., 1973, 94-97; RIT, p. 508; CIL II2/14, 1176-1186.

51. CIL II2/14, 1237-1267; D. Gorostidi, J. López Vilar, "Decurio Larum coloniae Tarraconensium. Nueva lectura de la inscripción RIT 401”, Epigraphica, 73, 2011, 376-380.

52. Cf. nota 12 .

53. J. M. Gurt, I. Rodà, “El pont del Diable. El monumento romano dentro de la política augustea”, AEspA 78, 2005, 147-165. 
Augusta podrían indicar una fundación anterior a Augusto ${ }^{54}$. G. Alföldy ${ }^{55}$ destacó que sólo tres ciudades en Hispania presentan estos dos nombres conjuntamente: Ilici, Barcino y Gades. Pero la arqueología no ofrece datos para poder aportar indicio alguno de una ciudad anterior a la que conocemos: la Barcino augustea en el llano, a pesar de que se continua insinuando una posible ubicación en el Montjuï ${ }^{56}$.

El emplazamiento elegido fue una ligera elevación de unos 11 metros de altura, abierta al mar y próxima al puerto principal de la desembocadura del Llobregat. En efecto, el puerto y la fachada marítima de la nueva colonia atestiguan que Barcino nació de cara al mar y que su zona portuaria tuvo una función primordial. No se trataba de aglutinar un núcleo poblacional, sino de crear un centro administrativo de dimensiones reducidas para controlar el territorio entre el Besós (Baetulo) y el Llobregat (Rubricatum), ya explotado ampliamente por su riqueza minera de la zona de Gavà y vitivinícola en época tardo-republicana que dio origen a la proliferación de villas muy productivas ${ }^{57} \mathrm{y}$ a un activo comercio marítimo que contaba además con la vía fluvial del Llobregat.

Pero, a pesar de sus reducidas dimensiones, no deja de sorprender la amplitud de los espacios intramuros y de las construcciones, tanto públicos como privados. Su patrimonio monumental va siendo estudiado y dado a conocer de manera regular desde la segunda mitad del siglo XX, primero con la publicación hasta 1980 de los Cuadernos de Arqueología e Historia de la Ciudad, continuados 25 años después, a partir de 2005, por Quarhis. Quaderns d'Arqueologia i Història de la Ciutat de Barcelona que se editan anualmente con toda puntualidad. También los volúmenes del Anuari d'Arquelogia i Patrimoni de Barcelona publican regularmente desde 2008 las excavaciones llevadas a cabo cada año y un esfuerzo admirable ha sido la redacción de la Carta arqueológica ${ }^{58}$; en este caso son encomiables los esfuerzos del Ayuntamiento de Barcelona a través del Institut de Cultura y del Servei d' Arqueologia, que ha puesto en marcha un plan Barcino, y del MUHBA (Museu d' Història de Barcelona).

Queremos en estas páginas, principalmente, someter a revisión y crítica las hipótesis más recientes lanzadas sobre diversos edificios de la arquitectura pública de Barcino.

54. I. Rodà, "Barcino. Su fundación y títulos honoríficos”, Symposion de ciudades augusteas. Bimilenario de Zaragoza (Zaragoza 1976), Zaragoza 1976, vol. II, 225-232.

55. G. Alföldy, “Administración, urbanización, instituciones, vida pública y orden social”, en J. M. Abascal, L. Abad (Eds.), Las ciudades y los campos de Alicante en época romana, Canelobre, 48, Alicante 2003, 35-57.

56. Abascal, loc. cit., 2006, 74.

57. V. Revilla, Producción cerámica, viticultura y propiedad rural en Hispania Tarraconensis (siglos I a.C.III d.C.), Cuadernos de Arqueología 8, Barcelona 1995; C. Carreras, J. Guitart, Barcino I. Marques i terrisseries d' àmfores al Pla de Barcelona, Corpus International des Timbres Amphoriques 15, Barcelona 2009; C. Carreras, A. López Mullor, J. Guitart, Barcino II. Marques i terrisseries d’àmfores al Baix Llobregat, Corpus International des Timbres Amphoriques 18, Barcelona 2013; C. Miró, J. Ramos, "Un exemple d' explotació de la carta arqueológica de Barcelona: les vil.les i els petits assentaments agrícoles. Una primera radiografia del territorium”, QUARHIS Quaderns d'Arqueologia i Història de la Ciutat de Barcelona, 9, 2013, 138-155.

58. http://cartaarqueologica.bcn.cat; C. Miró, "La carta arqueològica de Barcelona. Una eina de recerca i planificació urbana”, QUARHIS. Quaderns d'Arqueologia i Història de la Ciutat de Barcelona, 9, 2013, 196197. 


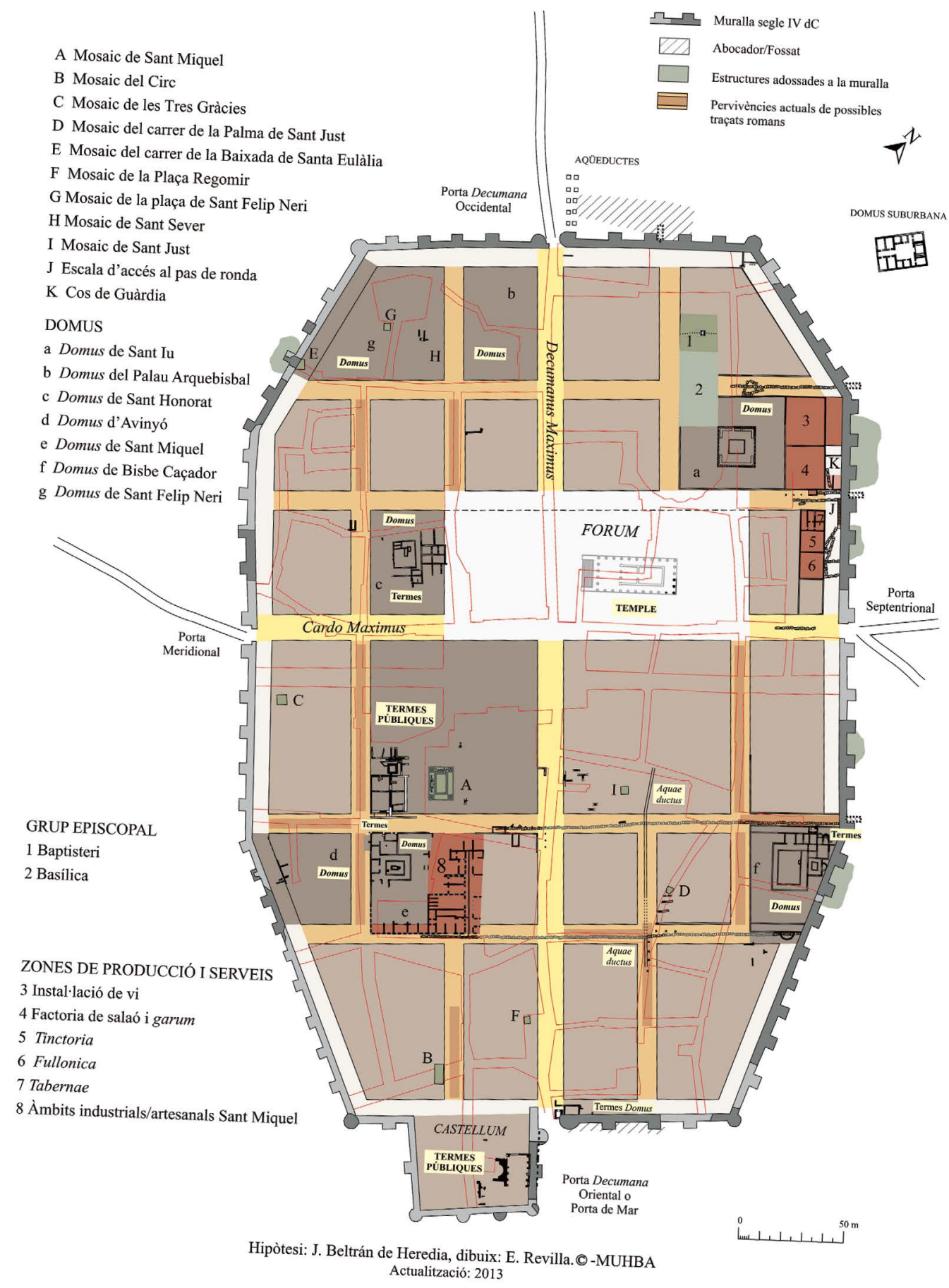

2.- Planta general de Barcino. J. Beltrán 2013, 19, fig. 1. 
La ciudad romana de Barcelona no dispuso de un amplio territorio, que fue objeto de una concisa centuriación ${ }^{59}$, ya que sabemos que sus límites (fines) estaban señalizados monumentalmente por el arco del puente de Martorell-Castellbisbal, en la orilla izquierda del Llobregat y un terminus augustalis localizado en el término municipal de Montornés (Vallès) podría ser el mojón que delimitara su ager en esta zona ${ }^{60}$.

Barcino se fundó con un plan absolutamente regular ya que las condiciones del terreno y la ausencia de construcciones anteriores lo permitían. Fue calificada por Pomponio Mela de parvum oppidum y, en efecto, de esta manera se nos presenta con las 10 hectáreas que abarca el espacio intramuros.

\section{Murallas}

Para magnificar su carácter de centro urbano se dotó a la nueva ciudad de un circuito de murallas de prestigio ya que ni el espesor de sus muros ni las circunstancias requerían una finalidad defensiva; de todas maneras la muralla sigue modelos propios de la arquitectura militar ya que al menos de su planificación se encargarían ingenieros del ejército y no es improbable que en la construcción hubiera podido participar alguna de las unidades legionarias que estaban en el mismo momento trabajando en el vecino puente de Martorell-Castellbisbal. Sabemos quién fue su comitente gracias a una inscripción que se ha tenido tradicionalmente como hallada en la montaña de Montjuïc que, después de dilatados debates, se ha relacionado con las murallas de la colonia; se trata del duunvir quinquenal Gaius Coelius cuya inscripción no deja lugar a dudas sobre la datación augustea ${ }^{61}$. A estas murallas, con sus ángulos achaflanados, se adosarían las murallas bajoimperiales, empezadas a construir a finales del siglo III,

59. J. Palet, Estudi territorial del Pla de Barcelona. Estructuració i evolució del territori entre l'època iberoromana i medieval, segles II-I aC-X-XI dC. Barcelona 1994; J. M. Palet, J.I. Fiz, H. A. Orengo, "Centuriació i estructuració de l'ager de la colònia Barcino: anàlisi arqueomorfològica i modulació del paisatge", QUARHIS. Quaderns d'Arqueologia i Història de la Ciutat de Barcelona, 5, 2009, 106-123; J. M. Palet, I. Rodà, "Estructuración del territorio y gestión del agua en los llanos litorales del nordeste de la Tarraconense", en F. Nasti, F. Reduzzi (Eds.), Per una comune cultura dell' acqua dal Mediterraneo all'America del Nord (Cassino-Napoli 2008). Alla memoria di Francesco Salerno, Cassino 2012, 30-31.

60. R. Járrega, I. Rodà, "El terminus Augustalis de Montornès: noves dades epigràłiques", Lauro, 16, 1999, 5-12; Gurt, Rodà, loc. cit., 2005; IRC I 200 en IRC V=G. Fabre, M. Mayer, I. Rodà, Inscriptions romaines de Catalogne V. Suppléments aux volumes I-IV et instrumentum inscriptum, París 2002, 37-38.

61. IRC IV=G. Fabre, M. Mayer, I. Rodà, Inscriptions romaines de Catalogne IV. Barcino, París 1997; O. Granados, "La primera fortificación de la colonia Barcino", Papers in Iberian Archaeology, BAR 193, 1984, 267-319; F. Puig, I. Rodà, "Las murallas de Barcino. Nuevas aportaciones al conocimiento de la evolución de sus sistemas de fortificación”, Murallas de ciudades romanas en el Occidente del Imperio: Lucus Augusti como paradigma. Actas del Congreso Internacional (Lugo 2005), Lugo 2007, 595-631 y Las murallas de Barcino/Les muralles de Barcino Barcelona 2010. 
cronología tradicional que se está viendo reconfirmada por los nuevos estudios examinando de nuevo los restos cerámicos y por una nueva lectura de los paramentos ${ }^{62}$.

\section{Templo}

Otro edificio público de la época fundacional es el templo, hexástilo, cuyos restos son visibles en la calle de Paradís, coronando el «mons Taber». La tipología de sus capiteles permite ubicar su construcción en los primeros tiempos del Imperio y, dado el arraigo del culto imperial en Barcino, es muy probable que éste fuera su destino a partir de la época de Tiberio. La posición del templo, presidiendo el foro colonial, se ha supuesto con el lateral paralelo al trazado del cardo maximus y la línea de fachada paralela al decumanus maximus. Se ubicó en el punto más alto de la colonia, teniendo en cuenta la topografía del terreno que es la que marca el urbanismo de Barcino. Parece pertenecer también al foro la estructura de grandes sillares (¿la curia?) sobre la que se apoyó la casa tardorromana de la calle de Sant Honorat ${ }^{63}$.

Muy recientemente se ha publicado una hipótesis rompedora: que el templo estuviera orientado hacia el norte, girando 90 grados su posición ${ }^{64}$. Es meritoria y útil la revisión de la documentación de J. Pujades y la producida a partir del siglo XIX, con una consulta de los datos arqueológicos, publicados o inéditos, que son georeferenciados. Pero lo más rompedor es el cambio de orientación propuesto tanto del foro como del templo en un giro de 90 grados, con lo que la fachada del templo miraría hacia la sierra de Collcerola. Aunque siempre es positivo reconsiderar los datos arqueológicos y ofrecer nuevas reflexiones, en este caso la hipótesis nos parece arriesgada al no disponer de las evidencias necesarias para fundamentar la propuesta y, sobre todo, pensamos que no se han tenido suficientemente en cuenta los siguientes problemas, además de otras cuestiones más particulares sobre la técnica y los sondeos, que necesitan una minuciosa observación:

En la topografía antigua, la ladera norte del «mons Taber» presentaba una fuerte pendiente. Se observa perfectamente en las salas del Museo de Historia de Barcelona (MUHBA),

62. A. Ravotto, "Material ceràmic procedent d'excavacions antigues (1949-1967) a la muralla de Barcino. Resultats preliminars", QUARHIS, Quaderns d'Arqueologia i Història de la Ciutat de Barcelona, 3, 2007, 221 222, 222, ID., "Datos para la cronología de la muralla bajoimperial de Barcino", Empúries, 56, 2009-2011, 249-276. Este autor ha leído en febrero de 2017 la tesis doctoral en la UAB sobre las murallas de la Barcelona romana.

63. A. Cortés, "L'arquitectura domèstica de la ciutat romana de Barcino", QUARHIS, Quaderns d'Arqueologia i Història de la Ciutat de Barcelona, 10, 2014, 46-57. Para la hipótesis de la curia, cf. J. Beltrán de Heredia, "Barcino, la topografía de una fundación augustea: trama urbana y edificios públicos", Tarraco Biennal. II Congrés Internacional d'Arqueologia i Món Antic. August i les províncies occidentals (Tarragona 2014), Tarragona 2015, 207-215; EAD., "Novetats sobre el fòrum de Barcino: la cúria i altres edificis públics", QUARHIS. Quaderns d'Arqueologia i Història de la Ciutat de Barcelona 11, 135-138.

64. H. A. Orengo, A. Cortés, “The Augustan Temple and Forum of the Colony of Barcino: a 90 degree Turn", Oxford Journal of Archaeology, 33, 1, 2014, 89-107; IDD., "El templo de Augusto de Barcino. Nuevas perspectivas de estudio", Empúries, 56, 2009-2011, 183-197. 
que se adentran en el subsuelo de la Catedral en la zona en la que se han puesto al descubierto el aula episcopal y el baptisterio paleocristianos. Los autores precisamente piensan que, con la nueva propuesta de orientación del foro, se revaloriza la posición del centro de culto cristiano, continuado hoy en día por la Catedral; pero la posición de la primera basílica en el cuadrante NW de Barcino nada tiene que ver con el templo de Augusto. Cabe pensar que el originario núcleo cristiano surgió a partir de una zona ocupada por domus privadas ${ }^{65}$.

Para construir el templo y el foro en la orientación norte-sur propuesta por H. A. Orengo y A. Cortés, se habría tenido que proceder a grandes obras de aterrazamiento de las que no se ha encontrado vestigio alguno.

La orientación norte-sur, además, daría la espalda al trazado urbano de la vía Augusta y se abre hacia las montañas de la sierra litoral, una zona que no tenía en absoluto importancia, ya que la ciudad miraba al mar. Hemos de tener en cuenta que la puerta principal de la muralla era la que se abría hacia la fachada marítima (puerta del Regomir o puerta decumana de mar) ${ }^{66}$.

No se tienen en cuenta los hallazgos de grandes sillares en la calle de Sant Honorat, que tienen que corresponder a una estructura pública (¿la curia?), con toda probabilidad al foro en su orientación este-oeste tradicional. Además, las tabernae que se dice invaden la zona son construcciones de la Antigüedad tardía, muy posteriores a la época fundacional del foro, relacionadas con la compartimentación de la domus ${ }^{67}$.

Las recientes excavaciones en la iglesia de los Santos Justo y Pastor van proporcionando evidencias de estructuras que siguen asimismo la orientación este-oeste ${ }^{68}$. Hoy no se puede observar pero, originariamente, el punto donde se ubica esta iglesia formaría también una pequeña colina, en paralelo a la que conocemos como «mons Taber» donde se alzó el templo romano parcialmente conservado.

Para dar respuesta a estas cuestiones sería muy interesante disponer de una planimetría arqueológica del mismo tipo que la publicada para Tarraco en el año 2007 a la que nos hemos referido al tratar de la capital de la Hispania citerior.

No tenemos información de otros edificios en Barcino relacionados con los espectáculos públicos. Cabe suponer que, dada su condición de colonia, habría podido disponer de un teatro, seguramente extramuros dadas las reducidas dimensiones del área urbana, pero por el momento no hay ningún indicio arqueológico de su existencia. Tal vez la importancia actual de Barcelona ha llevado a magnificar la que en realidad tuvo en época romana, suponiendo que tendría que estar dotada de grandes edificios para espectáculos.

65. J. Beltrán de Heredia, "Barcino, de colònia romana a Sede Regia visigoda, medina islàmica i ciutat comtal: una urbs en transformació”, QUARHIS. Quaderns d'Arqueologia i Història de la Ciutat de Barcelona, 9, 2013, 16-118, 23 con bibliografía anterior en la nota 12.

66. Puig, Rodà, loc. cit., 611-614, 624-626 y 2010, 43-48, 70-75; J. Hernández-Guasch, “The castellum of Barcino: from its early Roman Empire origins as a monumental public place to the Late Antiquity fortress", QUARHIS. Quaderns d'Arqueologia i Història de la Ciutat de Barcelona, 2, 2006, 74-91.

67. Beltrán de Heredia, loc. cit., 2013, 50-51.

68. Beltrán de Heredia, loc. cit., 2013, 28-30. 


\section{Anfiteatros}

Recientemente se han puesto en circulación dos propuestas diferentes sobre la realidad de posibles anfiteatros, a nuestro parecer ambas inviables.

La primera teoría apuntaba a su ubicación bajo la iglesia de Santa María del Mar ${ }^{69}$. Un argumento de peso según la autora se basa en su denominación también como Santa María de las Arenas en un documento del año 1104, pero dicha denominación no es antigua, ya que corresponde a una anotación del canónigo Campillo en el siglo XVIII ${ }^{70}$. Además podemos añadir que ya F. Carreras Candi afirmaba que la documentación medieval no se refiere nunca a Santa Maria del Mar como de las Arenas ${ }^{71}$, hecho que nos ha sido amablemente corroborado por el prof. Ph. Banks ${ }^{72}$ con un largo elenco de documentos de los siglos X-XII.

Por lo tanto, el argumento primero y principal de J. Sales para probar la existencia de un anfiteatro en Santa Maria del Mar resulta absolutamente inservible. Además la autora trae a colación realidades arqueológicas que todavía no han sido confirmadas por las excavaciones, como la probable presencia de una iglesia paleocristiana o la extrapolación de las descripciones de M. Ribas de los años 60 y 70 del siglo pasado.

El argumento definitivo para la no existencia de un anfiteatro en el área de Santa María de Mar ha venido proporcionado por las prospecciones geofísicas que han demostrado la imposibilidad de un terreno estable para una edificación tan sólida como un anfiteatro y tan sólo se ha podido excavar una extensa necrópolis tardorromana en una potente unidad de arenas $^{73}$. Por lo tanto, a la vista de las evidencias, pensamos que es imposible la presencia de un anfiteatro en la zona de Santa María del Mar, cuyo nombre como de las Arenas en el siglo XVIII recoge solamente eso, una zona arenosa.

69. J. Sales, "Santa María de las Arenas, Santa María del Mar y el anfiteatro romano de Barcelona”, Revista d'Arqueologia de Ponent, 21, 2011, 61-73.

70. Sales, loc. cit., 64. Rebate con razón esta interpretación de J. Sales y L. Conde en "Hipótesis sobre la posible ubicación del anfiteatro de Barcino", Pyrenae, 44-2, 2013, n. 17, citando el estudio de Bassegoda de 1925-1927.

71. F. Carreras y Candi, La ciutat de Barcelona, Geografia General de Catalunya, Barcelona s.d., 312-313, n. 748 .

72. Agradecemos a Philip Banks su comunicación oral y, además, la información de que, antes de que lo hiciera el canónigo Campillo pero también en el siglo XVIII, ya Pere Serra i Postius en 1734-1748 se refería a Santa María de las Arenas (Lo perquè de Barcelona y memòries de sas antiguedats, edición de Joan Tres i Arnal, Barcelona 2006, 69).

73. R. Julià, S. Riera, "Usos del sòl i activitats productives a Barcelona a partir de l' analisi paleoambiental de la llacuna litoral medieval del Pla de Palau”, QUARHIS. Quaderns d'Arqueologia i Història de la Ciutat de Barcelona, 6, 2010, 164-177 y "Proposta d'evolució del front marítim de Barcelona durant l' Holocè. A partir de la integració de dades geotècniques, intervencions arqueològiques i cronologies absolutes", QUARHIS. Quaderns d'Arqueologia i Història de la Ciutat de Barcelona, 8, 2012, 16-37. Sobre la necrópolis, vid. recientemente, J. Beltrán de Heredia, "Santa Maria del Mar: un enclave cultual de la Antigüedad tardía en el suburbium de Barcino", QUARHIS. Quaderns d'Arqueologia i Història de la Ciutat de Barcelona, 7, 2011, 109-114 y A. Martin, "Les àmfores de la necròpolis de Santa Maria del Mar", QUARHIS. Quaderns d'Arqueologia i Història de la Ciutat de Barcelona, 7, 2011, 144-165. 
La segunda hipótesis pretende ubicar un anfiteatro en el área de la iglesia de Santa Maria del Pi que había suscitado polémicas antiguas que ya fueron certeramente rebatidas en su día por A. Balil ${ }^{74}$. Ahora se vuelve de nuevo a replantear la cuestión, añadiendo a las cuestiones toponímicas la consideración de lo que se ha interpretado como unas huellas fosilizadas en el parcelario ${ }^{75}$ que, según el autor, perfilan un anfiteatro de enormes proporciones y obligan a proponer un recorrido algo rocambolesco de la vía Augusta para subsanar el trazado rectilíneo que partiría por la mitad el supuesto anfiteatro.

A pesar de los datos publicados sobre las excavaciones practicadas en la zona en los años 2007 y 2009, se ha querido demostrar contra viento y marea la realidad de un anfiteatro en esta zona. Para conseguirlo, se fuerzan las cronologías, ya que se relacionan con la fossa bestiaria unos grandes pilares cuya cronología es de época tardorromana o incluso medieval, según ha publicado su excavador ${ }^{76}$. La pretendida similitud que quiere resaltar L. Conde con las estructuras de la arena de otros anfiteatros, como el de Italica, resulta solamente formal ${ }^{77}$. A la vista de todo ello nos parece que tampoco es viable la existencia de un anfiteatro en esta ubicación. Para reforzar los argumentos podemos pensar en que, si bien el parcelario puede transparentar en ocasiones realidades antiguas, no siempre ocurre así; de esta manera, por ejemplo, se propuso una posible ubicación del anfiteatro de Córdoba junto al teatro, teoría que se ha visto descartada por la localización y excavación de anfiteatro en el área extramuros ${ }^{78}$.

Queremos una vez más hacer constar la importancia de reconsiderar y ver con nuevas perspectivas los hallazgos arqueológicos, pero siempre partiendo de una base científica sin forzar los datos en función de lo que se quiere demostrar, evitando siempre hacer un castillo de hipótesis ya que, si se procede de este modo, se ponen en circulación teorías que pueden causar una peligrosa cadena de errores.

\section{Otros edificios}

Respecto a lo que conocemos realmente sobre otros edificios públicos, nos tenemos que limitar a los relacionados con el agua. Por un lado, el suministro a base, creemos, de dos acueductos

y la red de canalizaciones y, por otro lado, los numerosos restos de termas bien sea públicas o

74. A. Balil, "Sobre el anfiteatro romano de Barcino", Cuadernos de Arqueología e Historia de la Ciudad II, 1961, 148-152.

75. Conde, loc. cit., 47-68.

76. A. Ravotto, "Placeta del Pi, 2", Anuari d'Arqueologia i Patrimoni de Barcelona 2009, Barcelona 2010, 100-101.

77. Conde, loc. cit., 56-58.

78. D. Vaquerizo, J. F. Murillo (Eds.), El anfiteatro romano de Córdoba y su entorno urbano, Monografías de Arqueología Cordobesa 19, vols. I-II, Córdoba 2010. Cf. para una primera hipótesis sobre la ubicación de anfiteatro en la zona del teatro y en eje con éste, a partir del análisis del parcelario actual, A. Ventura, “Los edificios de espectáculos” en D. Vaquerizo (Ed.), Córdoba en tiempos de Séneca, Córdoba 1996, 88-89. 
privadas $^{79}$, algunas próximas a la fachada marítima ${ }^{80}$, cuya monumentalidad va siendo cada vez más patente y resalta la importancia de la orientación de Barcino hacia el mar. Entre las termas públicas hay que destacar las excavadas en la plaza de Sant Miquel que fueron costeadas hacia el 125 d.C. por los Minicii Natales, padre e hijo y senadores oriundos de Barcino ${ }^{81}$.

Barcino reafirmó su carácter de centro urbano con todas las características innerentes mediante un suministro de agua por medio de acueductos. El más importante sin duda alguna era el que captaba sus aguas del río Besós (Baetulo) a la altura de Montcada y otro recogía las aguas de la sierra de Collcerola ${ }^{82}$, como prueban las entradas visibles junto a la torre número 1 de la muralla tardorromana (plaça Nova). Recientemente, sin embargo, se ha formulado una nueva hipótesis: que sólo existiera en época romana el acueducto del Besós que desdoblaría su trazado a escasos metros de la muralla, antes de entrar en el área intramuros ${ }^{83}$; realmente nos parece una solución poco práctica, que ocuparía innecesariamente un gran espacio intramuros y sin un sentido claro para la mejora del suministro hídrico a la colonia de Barcino, a pesar de que los datos que han llegado a nosotros sobre el acueducto de Collcerola parecen concentrarse en el siglo XIV y en las centurias siguientes, lo cual no imposibilita que se recuperara en tiempos posteriores un originario trazado de época romana ${ }^{84}$.

Por lo que a la red de canalizaciones internas se refiere, las excavaciones recientes están volviendo a poner en primer plano la importancia de las estructuras bajo la iglesia de los Santos Justo y Pastor para su mejor conocimiento, datos que vienen a sumarse a los ya conocidos en la calle de la Palma de Sant Just ${ }^{85}$.

79. C. Miró, F. Puig, "Edificios termales públicos y privados en Barcino”, en C. Fernández Ochoa, V. García Entero (Eds.) II Coloquio Internacional de Arqueología de Gijón. Termas romanas en el Occidente del Imperio (Gijón 1999), Gijón 2000, 171-178; C. Miró, "Els balnea de les domus de Barcino", QUARHIS. Quaderns d'Arqueologia i Història de la Ciutat de Barcelona, 7, 2011, 68-83.

80. Hernández Guasch, loc. cit.; Miró, Puig, loc. cit.; Beltrán de Heredia, loc. cit., 2013, 18-20.

81. IRC IV, 30; Miró, Puig, loc. cit., 173; I. Rodà, “Testimonios epigráficos de las termas”, en C. Fernández Ochoa, V. García Entero (Eds.), op. cit., 124-126.

82. M. Mayer, I. Rodà, "El abastecimiento de aguas en la Barcelona romana. Reconstrucción de su trazado", Segovia y la arqueología romana. Actas del Symposium (Segovia 1974), Barcelona 1977, 265-277; C. Miró, H. A. Orengo, "El cicle de l' aigua a Barcino. Una reflexió entorn a les noves dades arqueològiques", QUARHIS. Quaderns d'Arqueologia i Història de la Ciutat de Barcelona, 6, 2010, 108-133; H. A. Orengo, C. Miró, "Following Roman Waterways from a Computer Screen. GIS-based Approaches to the Analysis of Barcino's Aqueducts", en W. H. Verhagen-A. G. Posluschny, A. Danielisova (Eds.), Go Your Own Least Cost Path. Spatial technology and archaeological interpretation, BAR. Int. Ser. 2284, Oxford 2011, 47-53. Estos últimos autores (Miró y Orengo) exponen la hipótesis de que el acueducto de Collcerola corresponda a época medieval.

83. C. Miró, H. A. Orengo, "La topografía de l' aigua en época romana”, en M. Guàrdia (Ed.), La revolució de l' aigua a Barcelona, Barcelona 2011, 14-20.

84. Palet, Rodà, en Nasti, Reduzzi (Eds.), loc. cit., 33-34. Cf. n. 82.

85. A. Duran i Sanpere, Barcelona i la seva història. La formació d’ una gran ciutat, Curial, Barcelona 1972, 28-30; Miró, Orengo, loc. cit., 125-128. 
Hasta aquí lo que podemos comentar acerca de las construcciones públicas. Respecto al ámbito privado, hay que volver a destacar la considerable extensión de las domus excavadas ${ }^{86}$ y también que las necrópolis altoimperiales más próximas a la ciudad fueron sistemáticamente desmanteladas en el momento de erigir las segundas murallas a partir de finales del siglo III d.C. y parte de los monumentos funerarios sirvieron como material constructivo de las mismas; resultado de ello es la acumulación de inscripciones funerarias en las torres y lienzos próximos a las puertas por las que recorre el trazado urbano de la vía Augusta (el cardo maximus); a este respecto es significativa la concentración de epígrafes funerarios al derribar el Convento de la Enseñanza, próximo a la puerta del Call ${ }^{87}$. La única necrópolis visible in situ cerca de las murallas es la descubierta en la plaza de la Vila de Madrid, cuyas primeras tumbas podrían remontarse a un momento próximo a la etapa fundacional, según apuntan las recientes excavaciones que han permitido plantear la existencia de un collegium funeraticium y la antigüedad de las cupae structiles ${ }^{88}$. Cabe mencionar que en los últimos años se han venido excavando importantes zonas funerarias extramuros en el área de las Atarazanas, Calle del Hospital, Sant Pau del Camp y en la remodelación del mercado de Sant Antoni, cuyos resultados están en curso de estudio y de los que se ha ido dando puntual noticia en los Anuaris d'arqueologia i patrimoni de Barcelona, el último de los cuales correspondiente al año 2014 se ha publicado en 2016.

\section{Barcino. Culto imperial}

Uno de los motores activos en la vida municipal fue sin duda la institución del culto imperial, al igual que lo había sido en Tarraco donde este culto tenía un doble registro: el provincial y el municipal.

En Barcino sólo tenemos, lógicamente, el culto imperial a nivel municipal, pero con un enorme dinamismo. Como sucede en otras ciudades, el flaminato coronaba la carrera de los magistrados. Al lado de los flamines ejercían los seviri augustales, que formaban un colegio en el que se integraban y promocionaban los libertos. Las inscripciones barcinonenses son testimonios fehacientes y muy abundantes al respecto ${ }^{89}$. El colegio de los seviri augustales constituyó realmente un factor de gran peso e importancia en la vida municipal y económica

86. Cortés, loc. cit.; EAD., L' arquitectura domèstica d'època tardorepublicana $i$ altimperial a les ciutats romanes de Catalunya, Barcelona 2014, 122-131 y 239-251.

87. IRC IV, p. 419 y pp. 54-55.

88. AA.VV., "La necrópolis de la plaça Vila de Madrid", QUARHIS. Quaderns d'Arqueologia i Història de la Ciutat de Barcelona, 3, 2007, 12-123; J. Beltrán de Heredia, I. Rodà, "Las cupae de la Hispania Citerior: reflexiones sobre su origen y el caso de Barcino", en J. Andreu (Ed.), Las cupae hispanas: origen, difusión, uso, tipología, Zaragoza 2012, 77-110.

89. IRC IV, p. 412; I. Rodà, "El culte imperial i el seu reflex a la colònia de Barcino/El culto imperial y su reflejo en la colonia de Barcino", en E. Marin, I. Rodà (Eds.) Divo Augusto. La descoberta d’un temple romà a Croàcia/El descubrimiento de un templo romano en Croacia, Split 2004, 311-322 y 418-423 y EAD., en Nogales, González (Eds.), op. cit., 2007, 748-751. 
de Barcino. Nos inclinamos a interpretar una gran placa de mármol lunense, hallada en las excavaciones de la plaza de San Miguel, como la que identificaría la sede del colegio, más que una dedicatoria de los seviros augustales a la colonia. Traduciríamos el texto como: Los seviros augustales de la colonia Iulia Augusta Faventia Paterna Barcino ${ }^{90}$.

Ahora bien, si los hallazgos epigráficos en Barcino han sido generosos, los escultóricos correspondientes a espacios públicos han sido más bien escasos. Una estatua femenina hallada en la calle Paradís y conservada en el MAC podría corresponder muy bien a un personaje de la familia imperial, quizás a la misma Livia ${ }^{91}$, que hubiera podido haber formado parte de una galería de efigies de la familia julio-claudia, en la que quizás también se hubiera podido integrar el togado infantil con bulla hallado en las excavaciones de la calle Sant Honorat ${ }^{92}$.

Respecto a los restos arquitectónicos, por todo lo que acabamos de exponer, no deja de ser muy verosímil que el templo forense de la calle Paradís fuera dedicado a la figura del emperador, del Augusto, y no ya de Augusto propiamente dicho, denominación con la que es popularmente conocido. Sería un caso semejante al templo emeritense llamado de Diana ${ }^{93}$.

Por otro lado, recientemente se han identificado las estructuras localizadas en el subsuelo de la plaza de Sant Iu (en el MUHBA) como la sede de un collegium ${ }^{94}$, lo cual tiene rasgos de verosimilitud, aunque no puede asegurarse que pueda corresponder a un collegium Augustalium o Augusteum.

\section{Relaciones Tarraco-Barcino}

El carácter de ambas ciudades era muy diferente, como hemos ido viendo en las páginas precedentes: una era la gran capital provincial y plataforma pionera desde los tiempos de la segunda guerra púnica, la otra una pequeña colonia, construida totalmente ex novo en época augustea, dentro del programa de reestructuración del tercio norte peninsular, una vez acabadas definitivamente por M. Agripa las guerras cántabras en el año 19 a.C. ${ }^{95}$

90. IRC IV, 76.

91. Rodà, loc. cit., 2004, 316, 422.

92. M. Claveria, E. M. Koppel, I. Rodà, "Escultures romanes de Barcino", QUARHIS. Quaderns d’Arqueologia i Història de la Ciutat de Barcelona, 10, 2014, 30-53, núm. 1; Rodà, en Nogales, González (Eds.), loc. cit., 2007, 750-751.

93. J. Ma Álvarez, T. Nogales, Forum Coloniae Augustae Emeritae. “Templo de Diana”, Mérida 2003, 281303.

94. Cortés, loc. cit., 26-32; ID., op. cit., 2014, 122-126; Orengo, Cortés, loc. cit., 2014, 100-103.

95. I. Rodà, "El papel de Agripa en la trama urbana de la Hispania augustea", en A. Rodríguez Colmenero (Coord.), Los orígenes de la ciudad en el noroeste hispánico (Lugo 1996), vol. I, Lugo 1998, 275-293 y "La figura de Agripa en Hispania”, en C. Pérez González, E. Illaguerri (Coords.), Arqueología militar romana en Europa (Segovia 2001), Segovia 2005, 319-331. 
Los territorios de ambas eran colindantes. Muy extenso el de Tarraco y de poca amplitud el de Barcino. Los fines estaban marcados por el arco, de cronología augustea, en el estribo oriental del puente de Martorell-Castellbisbal sobre el río Llobregat ${ }^{96}$.

En ambos agri se implantaron villae, muchas de notable riqueza que, con un punto álgido en el reinado de Augusto, produjeron buenos y abundantes vinos: mejores los tarraconenses y muy abundantes los layetanos ${ }^{97}$. Los testimonios epigráficos evidencian la fuerte presencia de itálicos tanto en el ámbito urbano, como en la zona rural donde se cultivaba la viña, coincidiendo en ocasiones la onomástica de unos mismos personajes ${ }^{98}$.

Tanto Tarraco como Barcino disponían de puertos muy activos para la entrada y salida de todo tipo de productos y que, naturalmente, también sirvieron como vía de comunicación entre ambas ciudades, además de la vía terrestre mediante la gran arteria de la vía Augusta, cuyo trazado fue precisamente remodelado en el momento de la fundación de Barcino.

Por los dos puertos se exportaron los vinos de la zona, en las ánforas fabricadas localmente y entraron con gran abundancia, por ejemplo los mármoles de Luni-Carrara, principalmente en bruto para ser tallados in situ, y también las cerámicas de mesa de Italia, sur de la Narbonense y el norte de África sobre todo.

También las producciones artísticas elaboradas en los materiales locales revestidos de estuco de los primeros momentos del Imperio presentan tanto en Tarraco como en Barcino unas dependencias formales de los tipos itálicos, evidentes tanto en la arquitectura pública como privada. Lo comprobamos en los capiteles del teatro de Tarraco y en los del templo de Augusto en Barcino, al igual que en la escultura funeraria salida de los talleres de una y otra ciudad $^{99}$. En el caso de Tarraco, el material lapídeo salió de las canteras del Mèdol y en el de Barcino de las canteras de Montjuïc ${ }^{100}$. De todas maneras, también hay diferencias, como por

96. Gurt, Rodà, loc. cit.

97. Plinio, NH 14.71; M. Prevosti, A. Martin (Eds.), El vi tarraconense i laietà, ahir i avui. Actes del Simposium, Documenta 7, Tarragona 2009.

98. D. Gorostidi, Ager Tarraconensis 3. Les inscripcions romanes, Documenta 16, Tarragona 2010; Carreras, Guitart, op. cit. 2009; Carreras, López Mullor, Guitart, op. cit., 2013; I. Rodà, "Imago mortis: el componente itálico en el mundo funerario de Barcino y Tarraco", en J. Andreu, D. Espinosa, S. Pastor (Coords.) Mors omnibus instat. Aspectos arqueológicos, epigráficos y rituales de la muerte en el Occidente romano, Madrid, 2011, 233-254.

99. M. Claveria, "Los relieves funerarios en piedra de los talleres locales en Tarraco" en V. Gaggadis-Robin et alii (Eds.), Les ateliers de sculpture régionaux: techniques, styles et iconographie. Actes du Xe Colloque International sur l'art provincial romain (Arles-Aix-en-Provence 2007), Santander 2009, 495-504; E. M. Koppel, "Los retratos funerarios en piedra de los talleres locales en Tarraco" en Gaggadis-Robin et alii (Eds.), op. cit., 505-511; I. Rodà, "La escultura del sur de la Narbonense y del norte de Hispania Citerior: paralelos y contactos” en P. León, T. Nogales (Eds.) Actas de la III Reunión sobre escultura Romana en Hispania (Córdoba 1997), Madrid 2000, 173-196 y "Los talleres de la ciudad de Barcino (Barcelona)" en Gaggadis-Robin et alii (Eds.), op. cit., 513-528; ; J.A. Domingo, A. Garrido, R. Mar, "Talleres y modelos decorativos en la arquitectura pública del noreste de la Tarraconense en torno al cambio de era: el caso de Barcino, Tarraco y Auso" en Nogales, Rodà, (Eds.), op.cit., 2011, 851-862.

100. M. Boada (Dir.), El Mèdol, Gerona 2004; A. Álvarez et alii, Marbles and Stones of Hispania/Marbres i pedres d' Hispània/Mármoles y piedras de Hispania, Tarragona 2009, 86-93; A. Gutiérrez, Roman Quarries 
ejemplo la abundancia de altares monumentales con gorgoneia y de cupae en Barcino, tipos monumentales que son prácticamente inexistentes en Tarraco ${ }^{101}$.

Un producto que viajó por mar en gran abundancia desde Tarraco a Barcino fue la excelente caliza cretácica, la llamada piedra de Santa Tecla o marmor de Tarraco ${ }^{102}$. En efecto, en este material está manufacturada la mayor parte de los pedestales epigráficos de Barcino y también de otras ciudades vecinas, tanto en la costa (Baetulo, Iluro) como en el interior (Caldes de Montbui, posiblemente Aquae Calidae). Los bloques no debían llegar en bruto sino que, dadas las similitudes formales, debían llegar ya con las molduras que enmarcan el campo epigráfico. Incluso en ciertos casos creemos que podemos plantear que algunos textos pudieran ser inscritos en la propia capital provincial y ser transportados ya ultimados a la colonia de Barcino; es un estudio que tenemos en curso.

Por su parte, los textos de las inscripciones nos dan a conocer en algún caso la presencia de un barcinonense en Tarraco, como el Lucius Valerius Latinus que dedica un epígrafe, seguramente un pedestal, hoy perdido, al magistrado municipal y caballero, Lucius Caecina Severus ${ }^{103}$.

En Barcino no tenemos ninguna mención de una origo tarraconense entre las más de 300 inscripciones que ha proporcionado la ciudad, pero, en cambio, hay ejemplos de magistrados que ejercieron funciones tanto en Barcino como en Tarraco. Es el caso de Lucio Pedanio Clemente Senior que desempeñó en la primera mitad del siglo II d.C. todos los honores en su ciudad (Barcino) y fue duunvir quinquenal en Tarraco ${ }^{104}$.

Pero el caso más sintomático es el del liberto Lucio Licinio Secundo, que lo fue del influyente Lucio Licinio Sura en tiempos de Trajano. Se trata del personaje privado más homenajeado de todo el Imperio con sus más de 20 pedestales destinados a ser erigidos en el foro barcinonense ${ }^{105}$. En todos ellos, a excepción de los dedicantes, el texto es prácticamente el mismo, mencionando que primero fue seviro augustal de Tarraco y después lo fue de Barcino. De nuevo en ambas ciudades se nos muestra el dinamismo del culto imperial como elemento de promoción y en este caso, además, se nos evidencian a través de su liberto, las relaciones de Sura con Tarraco cuyos antepasados ya eran ricos propietarios en la zona, según atestigua el arco de Berà.

En otros casos no tenemos una relación atestiguada tan directamente, pero podemos plantear la hipótesis de que la familia senatorial barcinonense de los Minicii Natales, pudiera haber tenido una relación directa con Licinio Sura, ya que Minicio Natal padre tuvo el

in the Northeast of Hispania (Modern Catalonia), Documenta 10, Tarragona 2009, 89-101 y 146-158; A. Gutiérrez et alii, "Can a fire broaden our understanding of a Roman quarry?. The case of el Mèdol (Tarragona, Spain)” en P. Pensabene, E. Gasparini (Eds.), Asmosia X (Roma 2012), Roma 2015, vol. II, 779-789.

101. A. Balil, "Los 'gorgoneia' de Barcino", Faventia, 1/1, 1979, 63-70; M. Claveria, "Altares monumentales con pulvini del nordeste peninsular", en J. M. Noguera, E. Conde (Eds.), Escultura romana en Hispania $V$ (Murcia 2005), Murcia 2008, 345-396; Beltrán de Heredia, Rodà, loc. cit.

102. A. Àlvarez et alii, El marmor de Tarraco/Tarraco Marmor, Hic et Nunc 6, Tarragona 2009.

103. RIT 165=CIL II $2 / 14,1013$.

104. IRC IV, 69.

105. IRC IV, pp. 163-188, núms. 83-104. 
mando de una legión en Dacia, que proponemos que pudiera ser la VII Claudia o la V Macedónica, y coincidir con ello en la zona danubiana con Licinio Sura ${ }^{106}$. Tanto de Licinio Sura como de los dos Minicios tenemos pocos datos biográficos ${ }^{107}$, pero no resulta improbable que pudiéramos identificar a dos libertos en Barcino como libertos suyos en la primera parte del siglo II d.C. ${ }^{108}$. Asimismo resulta verosímil proponer que los Minicii barcinonenses pudieran tener clientes o libertos en Tarraco ${ }^{109}$.

Por otra parte, como ya hemos mencionado al tratar de Tarraco, la capital provincial fue un destino elegido con gusto por parte de los militares retirados, como también lo fue Barcino. Aquí contamos con un documento excepcional: es el del pedestal del centurión Lucio Cecilio Optato, licenciado con honor por los emperadores Marco Aurelio y Lucio Vero, que fue acogido en Barcino entre los ciudadanos inmunes y ejerció todos los cargos, siendo duunvir en tres ocasiones y coronando su carrera municipal como flamen Romae Divorum et Augustorum $^{110}$. Después de haberse convertido en uno de los más destacados notables de la ciudad, Cecilio Optato quiso dejar grabado en primera persona su donación a la res publica Barcinonensium, consistente en una donación de 7500 denarios cuyos intereses a un 6\% anual tenían que invertirse en un espectáculo de pugilato y un reparto de aceite en las termas públicas. Lo interesante para esta ocasión es el modus del legado: para que esta donación se llevara a cabo, los libertos de Cecilio Optato y los libertos de sus libertos y libertas a los que les fueran concedido el honor del sevirato, tenían que ser dispensados de todas las cargas que el mismo comportaba. Si esta disposición se incumpliera, los 7500 denarios tendrían que ser transferidos a la res publica Tarraconensium, para que, con las mismas condiciones, los espectáculos fueran organizados en Tarraco.

Esta inscripción, rebosante de interés, nos sirve para cerrar la síntesis de las relaciones de Tarraco y Barcino en los dos primeros siglos del Imperio, en las que personajes de toda condición social jugaron, como hemos visto, un importante papel y el culto imperial constituyó en ambas un elemento de gran vitalidad en la esfera pública.

\section{ADDENDUM}

Estando en prensa este artículo se han publicado sendos volúmenes y diversos trabajos en revistas y Actas de Congresos que no podemos añadir al texto, pero que colacionamos a continuación, citando los artículos referentes a las ciudades de Tarraco y Barcino en el Alto Imperio.

106. IRC IV, 30 у p. 92.

107. Rodà, en Piso, Varga (Eds.), loc. cit.

108. IRC IV, 1 y 191.

109. J. Andreu, P. Otiña, O. Curulla, "Los Minicii de Tarraco. En torno a un nuevo documento epigráfico tarraconense", Epigraphica LXX, 2008, 103-117 para los Minicii de Tarraco, Barcino y Emporiae.

110. IRC IV, 45; I. Rodà, "La inscripción de Lucio Cecilio Optato", Cuadernos de Arqueología e Historia de la Ciudad XVIII, 1980, 5-49. 
En el año 2013 tuvo lugar en Mérida la celebración del XVIII Congreso Internacional de Arqueología Clásica, con las Actas publicadas en 2 volúmenes, Mérida 2015. En el vol. I hay los siguientes trabajos:

1. J.M. Macias et alii, "Reconstrucción digital del anfiteatro romano de Tarraco (Hispania Tarraconensis) mediante escáner láser. Bases para el estudio analítico y estructural”, 87-90.

2. S. Vinci, J.M. Macias, M. Orellana, "Metodología y análisis fotogramétrico del muro de cierre de la plaza de representación del "foro provincial" de Tarraco (Hispania Tarraconensis)", 91-94.

3. M. Díaz, I. Teixell, "La plaza de representación del Concilium Provinciae Hispaniae Citerioris: soluciones y dudas sobre su interpretación arquitectónica”, 837-841.

4. C. Brull et alii, "El circo romano de Tarraco: nuevos datos arquitectónicos. La intervención arqueológica de la calle Enrajolat (Tarragona)", 871-874.

5. C, Miró, "Las termas marítimas de la colonia Barcino", 879-882.

En el vol. II, encontramos:

6. J.M. Macias et alii, "El templo de Augusto en Tarraco: últimas excavaciones y hallazgos", 1539-1543.

En el año 2014 se celebró en Tarragona el Segon Congrés Internacional d'arqueologia i món antic, dentro de la serie Tarraco Biennal, dedicado a "August i les províncies occidentals. 2000 aniversari de la mort d'August", con las Actas publicadas en Tarragona en 2015. En el vol. 1 se incluyen los artículos:

1. J. Beltrán de Heredia, "Barcino, la topografía de una fundación augustea: trama urbana y edificios públicos”, 207-215.

2. C. Miró, "El Pla Bàrcino: un projecte de ciutat per investigar i donar a conèixer la Colònia Iulia Augusta Faventia Paterna Barcino", 217-224.

En el volumen 2, se publica la ponencia de J. Ruiz de Arbulo, "Tarraco y Augusto entre la República y el Imperio", 151-166, a la que siguen 13 estudios a cargo de autores diversos que inciden en temas fundamentales de la arqueología de la ciudad de Tarraco (167-261). 
Por último, hemos de mencionar, en estos últimos años, publicaciones de conjunto sobre Tarraco:

J.M. Macias, I. Rodà, “Tarraco”, en A. Riera, J. Guitart, S. Giner, (Eds.), Ciutats mediterrànies: civilització i desenvolupament/Villes méditerranéennes: civilisation et développement, Barcelona 2015, 119-130.

J. M. Macias, I. Rodà, “Tarraco, the first capital”, Catalan Historical Review, 8, 2015, 9-28.

R. Mar, J. Ruiz de Arbulo, D. Vivó, J.A. Beltrán-Caballero, Tarraco. Arqueología y urbanismo de una capital provincial romana, vol. II, Tarragona 2015.

En 2016 se ha publicado el fascículo IV del CIL II2/14 correspondiente a la Colonia Iulia Triumphalis Tarraco, obra póstuma de G. Alföldy con la colaboración de H. Niquet. Este volumen completa los dos precedentes -fascículos II y III- consagrados a la ciudad de Tarraco, el III obra póstuma asimismo de G. Alföldy (2012) y el II también a cargo de G. Alföldy publicado en 2011 a quien queremos recordar de un modo especial en estas páginas por su ingente dedicación y por continuar siendo un maestro, más allá incluso de la fecha en que nos dejó. 